\title{
VAZHA OKUJAVA \\ (February 25, 1930 - March 13, 2011)
}

Professor Vazha Okujava, Doctor of Medicine, Full Member of the Georgian National Academy of Sciences, Honored Scientist, and an active member of IBRO and FENS, died on March 13, 2011. He was 81 years old. He passed away as an eminent scientist, a brilliant experimenter, a remarkable organizer of science, an extraordinary teacher, and an extremely kind, sympathetic, and wise researcher.

Professor Vazha Okujava was born on February 25, 1930. He graduated from the Tbilisi State Medical University. Vazha Okujava obtained a candidate degree in 1960 and a doctoral degree in medicine in 1969. From 1961, he was the Head of the Laboratory of Experimental Neurology in the Institute of Neurology (Tbilisi); the laboratory was later on transformed to an independent scientific institution. From 1969, V. Okujava occupied the Professor position in the Department of Animal and Human Physiology at the above University.

In 1974, Prof. Okujava was elected a Full Member of the Georgian National Academy of Sciences. From 1973 to 1975, he occupied the position of Vice-Rector of the Tbilisi State Medical University; from 1975 to 1980, he was Academician-Secretary of the Section of Physiology and Experimental Medicine at the Georgian Academy of Sciences. From 1980 to 1985, Prof. Okujava occupied the position of Rector of the Javakhishvili Tbilisi State University.

In 1975, Prof. Okujava was elected the President of the Georgian Physiological Society and occupied this position until the last day of his life. In 1975, he also became the Editor-in-Chief of the Biomedical Series of Proceedings of the Georgian Academy of Sciences and a member of the Editorial Boards of the international scientific journals Neurophysiology and Electroencephalography and Clinical Neurophysiology. From 1997, he was a member of the Editorial Board of the Epilepsy Research periodical. He was also a member of the European Academy of Epilepsy.

Okujava's monographs and articles were published in many countries and have earned him a welldeserved reputation. These publications are related to both fundamental problems of neurophysiology and issues of clinical neurology.

Professor Okujava was awarded the Beritashvili Prize in 1981 and the International Prize of Khorezm in 1999.

Okujava's brilliant career and high positions failed to overshadow his unbelievable love for experimental work, which he then spread to many of his students, who are now successfully working in many leading research centers in both Georgia and a number of foreign countries.

The image of Prof. Vazha Okujava as a prominent scientist, a good friend, and a great teacher will live forever in the hearts of his colleagues, friends, and grateful students.

Georgian Neuroscience Association Georgian Physiological Society 